\title{
Analisis Penerapan Media Pembelajaran Geogebra dalam Mengembangkan Kemampuan Komunikasi Matematis Siswa Pokok Bahasan Sistem Persamaan Linier Dua Variabel
}

Author:
Alvias Noviantika Arnanda $^{1}$
Dafik $^{2}$
Ervin Oktavianingtyas $^{3}$
Harmi $^{4}$
Indyah Firmani $^{5}$
Affiliation:
${ }^{1,2,3}$ University of Jember, East
Java, Indonesia
${ }^{3,4}$ SMP Negeri 1 Ngusikan,
Jombang, East Java, Indonesia
Corresponding author:
Alvias Noviantika Arnanda,
alviasnovian@ yahoo.com
Published: $16 / 3 / 2021$
Dates:
Accepted: $8 / 3 / 2021$

Author:

Dafik $^{2}$

Ervin Oktavianingtyas ${ }^{3}$

Harmi $^{4}$

Indyah Firmani ${ }^{5}$

\section{Affiliation:}

$1,2,3$ University of Jember, East

Java, Indonesia

${ }^{3,4}$ SMP Negeri 1 Ngusikan,

Jombang, East Java, Indonesia

\section{Corresponding author:}

Alvias Noviantika Arnanda, alviasnovian@yahoo.com

\section{Dates:}

Accepted: 8/3/2021

Published: 16/3/2021

\begin{abstract}
Abstrak. Tujuan penelitian ini adalah untuk mengetahui aktivitas belajar siswa pada mata pelajaran Sistem Persamaan Linier Dua Variabel dengan menggunakan media pembelajaran Geogebra, untuk mengetahui apakah ada peningkatan kemampuan komunikasi matematis siswa pada mata pelajaran Sistem Persamaan Linier Dua Variabel dengan menggunakan media pembelajaran Geogebra. Media pembelajaran Geogebra, dan untuk mendeskripsikan keterampilan komunikasi matematis siswa pada mata pelajaran Sistem Persamaan Linier Dua Variabel dengan menggunakan media pembelajaran Geogebra. Penelitian ini dilakukan di SMP Negeri 1 Ngusikan. Penelitian ini menerapkan penelitian kualitatif. Pengumpulan data dilakukan dengan tes dan wawancara. Untuk menganalisis kemampuan komunikasi matematis siswa, peneliti melakukan prates dan pascates. Hasil penelitian menunjukkan bahwa penerapan media pembelajaran Geogebra dapat meningkatkan kemampuan komunikasi matematis siswa pada mata pelajaran Sistem Persamaan Linier Dua Variabel.
\end{abstract}

Kata kunci: Keterampilan komunikasi matematik, Geogebra, Sistem Persamaan Linear Dua Variabel

\begin{abstract}
The objective of this research was to find out students' learning activity on Linear Equation System of Two Variables subject using Geogebra learning media, to find out if therewas an increase in the students' mathematic communication skills on Linear Equation System of Two Variables subject using Geogebra learning media, and to describe the students' mathematic communication skills on Linear Equation System of Two Variables subject using Geogebra learning media. This research was conducted at SMP Negeri 1 Ngusikan. This research applying qualitative research. The data were collected by tests and interview. To analyzing the students' mathematic communication skills, the researcher did pre-test and post-test. The result showed that the application of Geogebra learning media can increase the students' mathematic communication skills on Linear Equation System of Two Variables subject.
\end{abstract}

Keywords: Mathematic communication skills, Geogebra, Linier Equation System of Two Variable

\section{JoMEaL}

Copyright:

This work is licensed under a Creative Commons Attribution-ShareAlike 4.0 International License.

Read online:

https://jurnal.unej.ac.id/index.php/JOMEAL/index or scan barcode beside.

How to cite this article:

Arnanda, A., Dafik, D., Oktavianingtyas, E., Harmi, H., \& Firmani, I. (2021). Analisis Penerapan Media Pembelajaran Geogebra dalam Mengembangkan Kemampuan Komunikasi Matematis Siswa Pokok Bahasan Sistem Persamaan Linier Dua Variabel. Journal of Mathematics Education and Learning, 1(1), 38-50. Retrieved from https://jurnal.unej.ac.id/ index.php/JOMEAL/article/view/24374 


\section{Pendahuluan}

Matematika merupakan sumber dari ilmu-ilmu lain (Monalisa \& trapsilasiwi, 2015; Faradina, Sunardi, \& trapsilasiwi, 2016). Matematika terbentuk sebagai hasil pemikiran manusia berhubungan dengan ide, proses dan penalaran (Suherman, 2013). Objek matematika adalah benda pikiran yang sifatnya abstrak dan tidak dapat diamati oleh pancaindra. Belajar matematika merupakan salah satu sarana berpikir ilmiah dan logis serta mempunyai peran penting dalam upaya meningkatkan kualitas sumber daya manusia (Sholikhah, Trapsilasiwi, \& Suharto, 2018). Berdasarkan diskusi penelitian yang dilakukan oleh Siregar, para subjek (siswa) menganggap matematika sebagai mata pelajaran yang secara umum cukup sulit (Siregar, 2017). Sehingga hal tersebut berpengaruh terhadap hasil belajar matematika siswa. Hal ini, merupakan tantangan bagi seorang guru untuk membuat suasana kelas menjadi menyenangkan sehingga siswa tertarik mempelajari matematika. Seorang guru dituntut harus kreatif dan inovatif untuk mendorong minat siswa dalam belajar, salah satu upaya yang bisa dilakukan adalah dengan menggunakan media pembelajaran. Inovasi yang dapat guru gunakan untuk adalah penggunaan media pembelajaran berbasis teknologi (Oktavianingtyas, Salama, Fatahillah, Monalisa, \& Setiawan, 2018).

Media pembelajaran yang dimaksud ialah media pembelajaran berbasis Information and Comunication Technology (ICT) yang dapat menambah minat siswa dalam proses pembelajaran, serta dapat memudahkan siswa untuk berperan aktif dalam kegiatan pembelajaran. Pemakaian media pembelajaran dalam proses pembelajaran matematika dapat membangkitkan keinginan, motivasi, dan rangsangan kegiatan belajar matematika. Tujuannya untuk mengefektifitaskan proseskomunikasi pembelajaran sehingga tercapai tujuan pembelajaran, serta untuk meningkatkan kemampuan siswa dalam berbagai hal (Agung \& Masduki, 2013).

Salah satu tujuan pembelajaran matematika berdasarkan Permendiknas Nomor 22 Tahun 2006 tentang Standar Isi Mata Pelajaran Matematika yaitu dapat mengkomunikasikan matematikaitu sendiri dengan simbol, tabel, diagram atau media lain untuk memperjelas keadaan atau masalah.Hal ini sejalan dengan lima kemampuan dasar yang diungkapkan oleh NTCM yaitu kemampuan mengorganisasi dan mengkonsolidasi pikiran matematika melalui komunikasi secara lisan maupun tertulis, mengkomunikasikan gagasan matematika secara logis dan jelas kepada orang lain, menganalisis dan mengevaluasi pikiran matematika dan strategi yang digunakan orang lain, serta menggunakan matematika untuk menyatakan ide-ide atau gagasan matematika secara tepat $(\mathrm{NCT}<$, 2000).

Kemampuan komunikasi matematis yang baik dibutuhkan untuk menyampaikan pemahaman, ide, dan argumen dalam pemecahan masalah matematika baik secara tulisan maupun lisan agar pemahaman, ide, dan argumentasi tersebut dapat dipahami dengan baik oleh orang lain (Kurnia Setiawani, \& Kristianam 2015; Laksananti, Setiawan, \& Setiawani, 2017). Salah satu materi pada pembelajaran matematika yang memerlukan kemampuan sesuai dengan indikator kemampuan komunikasi matematis adalah Sistem Persamaan Linier Dua Variabel. Saat ini kemampuan komunikasi matematis siswa di sekolah masih tergolong rendah. Hal ini sejalan dengan hasil perhitungan TIMSS pada tahun 2007 melaporkan bahwa siswa Indonesia masih sangat lemah pada kemampuan komunikasi matematis. Menurut penelitian yang dilakukan oleh Putri, di lapangan guru cenderung menggunakan metode pembelajaran yang kurang variatif, dimana guru masih menggunakan metode ceramah dalam mengajar (Nurlaila, Sariningsih, \& Maya, 2018; Putri, 2018). Oleh sebab itu digunakan metode pembelajaran dengan bantuan media pembelajaran yang diharapkan dapat mengubah cara komunikasi guru dan siswa sehingga dapat berjalan dua arah, dan 
siswa tidak cenderung hanya menerima materi dari guru. Media sebagai penyaji dan penyalur pesan dapat mewakili guru menyampaikan informasi lebih teliti, jelas, dan menarik. Tujuannya untuk mengefektifitaskan proses komunikasi pembelajaran sehingga tercapai tujuan pembelajaran (Fatoni, Faizal, Dafik, \& Fatahillah, 2017).

Media pembelajaran yang digunakan untuk menilai kemampuan komunikasi matematis siswa salah satunya adalah Geogebra. Geogebra merupakan salah satu software yang dapat membantu dalam pembelajaran matematika, bahkan juga dapat membantu dalam penulisan bahan ajar, selain itu Geogebra juga dapat digunakan sebagai alat bantu untuk menyelesaikan soal. Kita hanya perlu menyediakan komputer yang sudah terinstal software Geogebra atau juga bisa diakses di internet.

Berdasarkan kurikulum 2013, satu diantara materi yang diajarkan di kelas VIII SMP adalah sistem persamaan linier dua variabel (SPLDV). Ketika pembelajaran di kelas berlangsung, sering kali dijumpai beberapa siswa mengalami kesulitan belajar termasuk pada materi SPLDV khususnya jika disajikan dalam bentuk soal cerita. Siswa merasa kesulitan dalam memahami masalah dalam soal cerita dan menafsirkan ke dalam model matematika. Hal ini sejalan dengan Minarti yang menyatakan bahwa siswa merasa kesulitan dalam memahami masalah dalam soal cerita dan menafsirkan ke dalam kalimat matematika (Minarti, 2013).

Tabel 1. Indikator Komunikasi Matematis

\begin{tabular}{|c|c|c|c|}
\hline \multirow[t]{2}{*}{ Indikator NCTM } & \multicolumn{2}{|c|}{ Penjabaran Indikator } & \multirow{2}{*}{ Keterkaitan Media } \\
\hline & Komunikasi tulis & $\begin{array}{c}\text { Komunikasi } \\
\text { lisan }\end{array}$ & \\
\hline $\begin{array}{l}\text { 1. Kemampuan } \\
\text { mengekspresikan } \\
\text { ide-ide matematis } \\
\text { melalui lisan, } \\
\text { tulisan, dan } \\
\text { mendemonstrasikan } \\
\text { serta } \\
\text { menggambarkan } \\
\text { secara visual. }\end{array}$ & $\begin{array}{l}\text { Mengekspresikan } \\
\text { gagasan matematika } \\
\text { dengan menuliskan } \\
\text { informasi yang adapada } \\
\text { permasalahandengan } \\
\text { menuliskanapa yang } \\
\text { diketahuidan ditanya. }\end{array}$ & $\begin{array}{l}\text { Mengekspresikan } \\
\text { informasi yang } \\
\text { ada pada } \\
\text { permasalahan } \\
\text { dengan } \\
\text { menyebutkan apa } \\
\text { yang diketahui } \\
\text { dan ditanya. }\end{array}$ & $\begin{array}{l}\text { Siswa diminta } \\
\text { memahami } \\
\text { menjelaskan secara lisan } \\
\text { dan menginput data pada } \\
\text { tempat yang telah } \\
\text { tersedia. }\end{array}$ \\
\hline $\begin{array}{l}\text { 2. Kemampuan } \\
\text { memahami, } \\
\text { menginterpretasikan, } \\
\text { dan mengevaluasi } \\
\text { ide-ide matematis } \\
\text { baik secara lisan, } \\
\text { tulisan, maupun }\end{array}$ & $\begin{array}{l}\text { Memahami dan } \\
\text { menginterpretasikan } \\
\text { gagasan dengan } \\
\text { menuliskan strategi dan } \\
\text { langkah penyelesaian } \\
\text { permasalahan secara } \\
\text { runtut dan } \\
\text { sistematis. }\end{array}$ & $\begin{array}{l}\text { Menjelaskan } \\
\text { strategi dan } \\
\text { langkah-langkah } \\
\text { penyelesaian dari } \\
\text { permasalahan } \\
\text { dengan runtut } \\
\text { dan sistematis. }\end{array}$ & $\begin{array}{l}\text { Siswa mengikuti } \\
\text { prosedur yang ada pada } \\
\text { media pembelajaran dan } \\
\text { menjelaskan kembali } \\
\text { secara tulisdan lisan. }\end{array}$ \\
\hline
\end{tabular}




\begin{tabular}{|c|c|c|c|}
\hline \multirow[t]{2}{*}{ Indikator NCTM } & \multicolumn{2}{|c|}{ Penjabaran Indikator } & \multirow{2}{*}{ Keterkaitan Media } \\
\hline & Komunikasi tulis & $\begin{array}{c}\text { Komunikasi } \\
\text { lisan }\end{array}$ & \\
\hline $\begin{array}{l}\text { dalam bentuk visual } \\
\text { lainnya. }\end{array}$ & $\begin{array}{l}\text { Mengevaluasi gagasan } \\
\text { dengan menuliskan } \\
\text { kesimpulan diakhir } \\
\text { penyelesaian } \\
\text { permasalahan. }\end{array}$ & $\begin{array}{l}\text { Mengevaluasi } \\
\text { gagasan dengan } \\
\text { mengungkapkan } \\
\text { kesimpulan di } \\
\text { akhir } \\
\text { penyelesaian } \\
\text { permasalahan. }\end{array}$ & $\begin{array}{l}\text { Menuliskan dan } \\
\text { mengkomunikasikan } \\
\text { kesimpulan serta } \\
\text { melakukan input hasil } \\
\text { akhir. }\end{array}$ \\
\hline $\begin{array}{l}\text { 3. Kemampuan dalam } \\
\text { menggunakan } \\
\text { istilah-istilah, } \\
\text { notasi-notasi } \\
\text { matematika dan } \\
\text { strukturnya untuk } \\
\text { menyajikan ide-ide } \\
\text { serta } \\
\text { menggambarkan } \\
\text { hubungan-hubungan } \\
\text { dan model-model } \\
\text { situasi. }\end{array}$ & $\begin{array}{l}\text { Menggunakan simbol- } \\
\text { simbol matematika } \\
\text { dalammenuliskan } \\
\text { penyelesaian } \\
\text { permasalahan. }\end{array}$ & $\begin{array}{l}\text { Mengungkapkan } \\
\text { penggunaan } \\
\text { simbol-simbol } \\
\text { matematika pada } \\
\text { penyelesaian } \\
\text { permasalahan }\end{array}$ & $\begin{array}{l}\text { Menginput nilai yang } \\
\text { sesuai dengansimbol } \\
\text { dan istilah matematika } \\
\text { yang telah tersedia pada } \\
\text { media. }\end{array}$ \\
\hline
\end{tabular}

Berdasarkan penjelasan di atas, maka penelitian ini dilakukan dengan tujuan untuk mengetahui aktivitas belajar siswa menggunakan Geogebra, pengaruh pemanfaaatan software Geogebra, dan mendeskripsikan komunikasi matematis siswa pada pokok bahasan SPLDV menggunakan media pembelajaran Geogebra, oleh karena itu didapatkan judul penelitian berupa "Analisis Penerapan Media Pembelajaran Geogebra Dalam Mengembangkan Kemampuan Komunikasi Matematis Siswa Pokok Bahasan Sistem Persamaan Linier Dua Variabel”

\section{Metode Penelitian}

Jenis penelitian yang digunakan ialah penelitian kualitatif. Penelitian kualitatif ini bertujuan untuk mendeskripsikan peningkatan komunikasi matematis siswa dalam pembelajaran tanpa dan menggunakan Geogebra pada materi SPLDV. Subjek pada penelitian ini merupakan siswa SMP Negeri 1 Ngusikan. Penelitian ini terdiri dari beberapa tahap, yang pertama ialah pendahuluan. Pada pendahuluan dilakukan studi pendahuluan tentang komunikasi matematis siswa dan Geogebra serta membuat perencanaan terkait penelitian yang akan dilaksanakan. Tahap ke-2 observasi awal, selanjutnya dilakukan penentuan subjek, dengan klasifikasi tingkat kemampuan komunikasi matematis tinggi, sedang, dan rendah, sesuai dengan kelas interval kemampuan komunikasi matematis siswa pada Tabel 2.

Tabel 2. Kelas Interval Komunikasi Matematis

\begin{tabular}{|c|c|c|}
\hline No. & Kelas Interval & Kelompok Siswa \\
\hline 1 & $Q_{2} \leq$ skor $\leq$ skor maksimal & Tinggi \\
\hline 2 & $Q_{1} \leq$ skor $<Q_{2}$ & Sedang \\
\hline 3 & skor minimal $\leq$ skor $<Q_{1}$ & Rendah \\
\hline
\end{tabular}




$$
\begin{aligned}
& \text { Sumber: (Sudjana, 2002) } \\
Q_{1}= & \text { skor minimal }+P \\
Q_{2}= & Q_{1}+P
\end{aligned}
$$

Pada tahap ke-4 pembuatan instrumen yang terdiri dari soal tes dan wawancara. Instrumen kemudian diuji validasi, setelah instrumen sudah valid dilakukan pembelajaran menggunakan media pembelajaran. Kemudian mengambil data dan dianalisis untuk mendapat kesimpulan.

\section{Hasil dan Pembahasan}

Berdasarkan analisis data yang telah dilakukan terhadap nilai ulangan harian dan nilai tes hasil belajar siswa pada kegiatan penelitian yang telah dilaksanakan menunjukan perbedaaan, yakni ratarata nilai ulangan harian adalah 48 sedangkan rata-rata pada nilai tes adalah 54. Kenaikan nilai tes menggunakan media pembelajaran Geogebra pada pokok bahasan Sistem Persamaan Linier Dua Variabel memberikan dampak positif. Selain menjadi daya tarik dalam belajar, penggunaan media pembelajaran Geogebra juga memudahkan siswa untuk mengerjakan soal Sistem Persamaan Linier Dua Variabel.

Tujuan penelitian ini yang pertama untuk mengetahui aktivitas belajar siswa pada pokok bahasan Sistem Persamaan Linier Dua Variabel menggunakan Geogebra. Aktivitas belajar siswa pada pokok bahasan dapat diketahui dari hasil observasi. Berdasarkan observasi yang telah dilakukan, siswa mengikuti prosedur pembelajaran sesuai yang telah direncanakan. Siswa menunjukan ketertarikan dalam proses pembelajaran menggunakan media Geogebra. Mereka mengikuti pembelajaran dengan antusias. Berani bertanya ketika merasa kurang paham terhadap apa yang telah disampaikan. Dan beberapa siswa juga bersedia menjawab pertanyaan yang diberikan oleh guru. Hal ini menunjukan aktivitas belajar siswa dalam pokok bahasan Sistem Persamaan Linier Dua Variabel menggunakan Geogebra cukup baik dan menarik.

Media Pembelajaran yang digunakan ialah media pembelajaran yang telah dikembangkan oleh Muhammad Taufik Hidayat, S.Pd dengan berbantuan Software Geogebra. Pada media Geogebra tersebut ada beberapa menu, yakni petunjuk, home, silabus, materi, latihan. Pada menu "Home" adalah cover dari media yang digunakan. Pada menu "Silabus" berisi tentang Kompetensi Inti, Kompetensi Dasar, Indikator dan Tujuan Pembelajaran. Pada menu "Materi" terdapat materi tentang Sistem Persamaan Linier Dua Variabel. Pada menu "Latihan" terdapat soal-soal tentang Sistem Persamaan Linier Dua Variabel.

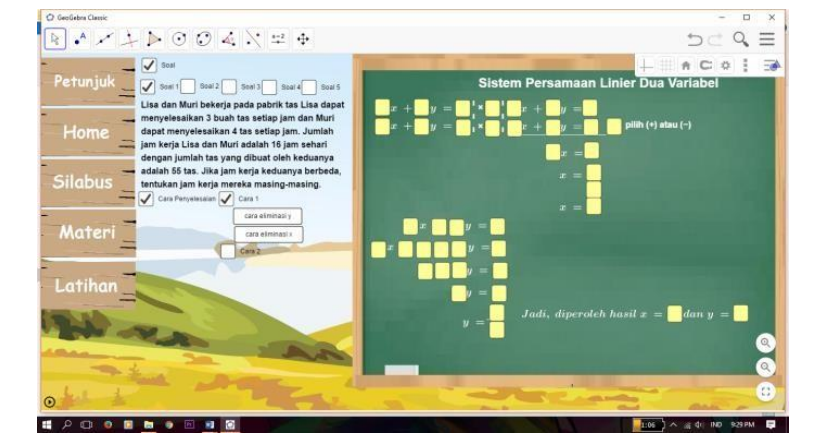

Gambar 1. Media Pembelajaran Berbantuan Geogebra

Pada gambar tersebut terdapat kolom-kolom dan petunjuk yang mengarahkan siswa untuk memahami dan menginterpretasikan gagasan dengan melakukan input data pada kolom berdasarkan 
petunjuk yang tersedia pada media pembelajaran tersebut, sebagai suatu strategi dan langkahlangkah penyelesaian permasalahan secara runtut dan sistematis. Hal ini mendukung proses peningkatan kemampuan komunikasi matematis siswa khususnya kemampuan komunikasi matematis tulis.

Tujuan penelitian ini yang kedua untuk mengetahui adakah peningkatan kemampuan komunikasi matematis siswa pada pokok bahasan Sistem Persamaan Linier Dua Variabel menggunakan Geogebra. Berdasarkan perbandingan nilai ulangan harian dan tes setelah menggunakan media pembelajaran Geogebra, kemampuan komunikasi matematis siswa meningkat. Hal ini dapat dilihat dari jawaban siswa, sebagian siswa menuliskan informasi yang ada pada permasalahan yang memenuhi salah satu indikator komunikasi matematis siswa. Selain itu siswa juga menuliskan langkah-langkah penyelesaian permasalahan secara runtut dan membuat pemisalan permasalahan dengan menggunakan simbol, hal ini memenuhi indikator komunikasi matematis siswa.

Tujuan penelitian ini yang ketiga untuk mendeskripsikan kemampuan komunikasi matematis siswa pada pokok bahasan Sistem Persamaan Linier Dua Variabel. Deskripsi kemampuan komunikasi matematis siswa pada pokok bahasan Sistem Persamaan Linier Dua Variabel dapat dilihat berdasarkan nilai sesudah dan sebelum menggunakan media.

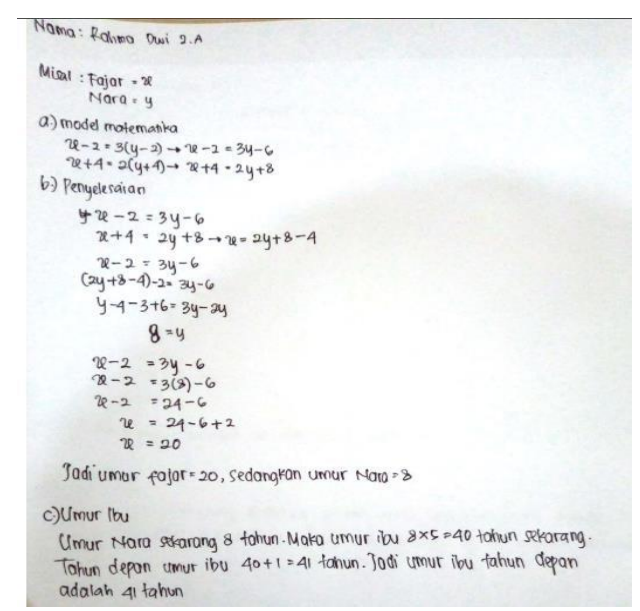

Gambar 2. Hasil Pekerjaan Siswa ke 1

Dapat dilihat dari jawaban siswa ke 1. Sesuai dengan indikator komunikasi matematis siswa ke 1 tidak menuliskan informasi dalam permasalahan. Siswa ke 1 menuliskan kalimat matematika dari permasalahan yang diberikan dengan lengkap dan benar. Siswa ke 1 menuliskan langkahlangkah dalam menyelesaikan permasalahan dengan lengkap dan benar. Siswa ke 1 memberikan kesimpulan diakhir penyelesaian dengan lengkap dan benar. Siswa ke 1 menuliskan simbol matematika dengan lengkap dan benar.

Pada tes kemampuan komunikasi matematis lisan siswa ke 1 mengucapkan informasi yang terdapat dalam permasalahan dengan lengkap, benar, tetapi tidak lancar. Siswa ke 1 mengucapkan permisalan masalah kedalam model matematika dengan benar tetapi tidak lancar. Siswa ke 1 menjelaskan langkah-langkah penyelesaian masalah dengan benar, runtut tetapi tidak lancar. Siswa ke 1 tidak memberikan kesimpulan diakhir penyelesaian. Siswa ke 1 mengucapkan simbol matematika dengan lengkap, benar tetapi tidak lancar. 


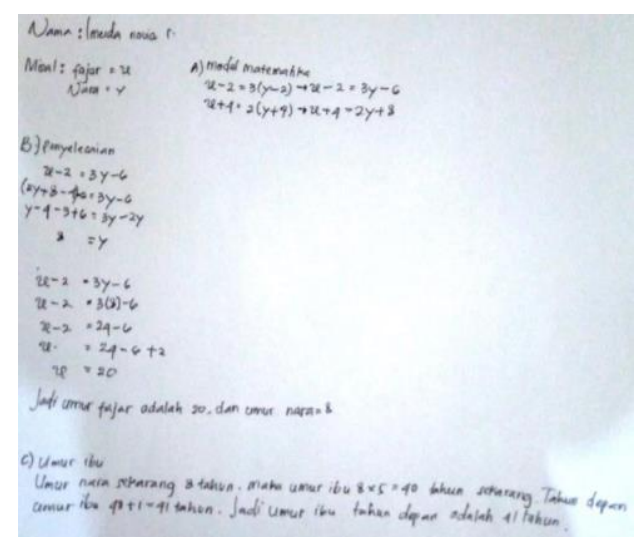

Gambar 3. Hasil Pekerjaan Siswa ke 2

Dapat dilihat dari jawaban siswa ke 2. Sesuai dengan indikator komunikasi matematis siswa ke 2 tidak menuliskan informasi dalam permasalahan. Siswa ke 2 menuliskan kalimat matematika dari permasalahan yang diberikan dengan lengkap dan benar. Siswa ke 2 menuliskan langkahlangkah dalam menyelesaikan permasalahan tidak lengkap tetapi benar. Siswa ke 2 memberikan kesimpulan diakhir penyelesaian dengan lengkap dan benar. Siswa ke 2 menuliskan simbol matematika dengan lengkap dan benar.

Pada tes kemampuan komunikasi matematis lisan siswa ke 2 mengucapkan informasi yang terdapat dalam permasalahan dengan lengkap, benar, tetapi tidak lancar. Siswa ke 2 mengucapkan permisalan masalah kedalam model matematika dengan benar tetapi tidak lancar. Siswa ke 2 menjelaskan langkah-langkah penyelesaian masalah dengan benar, runtut tetapi tidak lancar. Siswa ke 2 tidak memberikan kesimpulan diakhir penyelesaian. Siswa ke 2 mengucapkan simbol matematika dengan tidak lengkap dan tidak lancar tetapi benar.

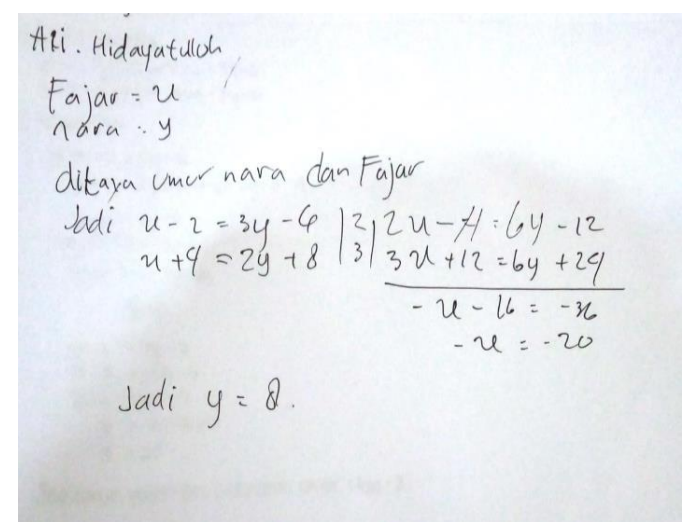

Gambar 4. Hasil Pekerjaan Siswa ke 3

Dapat dilihat dari jawaban siswa ke 3. Sesuai dengan indikator komunikasi matematis siswa ke 3 menuliskan informasi ditanya saja dalam permasalahan dengan benar. Siswa ke 3 tidak menuliskan kalimat matematika dalam permasalahan yang diberikan. Siswa ke 3 menuliskan langkah-langkah dalam menyelesaikan permasalahan tidak lengkap tetapi benar. Siswa ke 3 tidak memberikan kesimpulan diakhir penyelesaian. Siswa ke 3 menuliskan simbol matematika dengan lengkap dan benar.

Pada tes kemampuan komunikasi matematis lisan siswa ke 3 mengucapkan informasi yang terdapat dalam permasalahan tidak lengkap dan tidak lancar tetapi benar. Siswa ke 3 tidak dapat mengucapkan permisalan masalah kedalam model matematika. Siswa ke 3 menjelaskan langkah- 
langkah penyelesaian masalah dengan benar, runtut tetapi tidak lancar. Siswa ke 3 tidak memberikan kesimpulan diakhir penyelesaian. Siswa ke 3 mengucapkan simbol matematika dengan tidak lengkap dan tidak lancar tetapi benar.

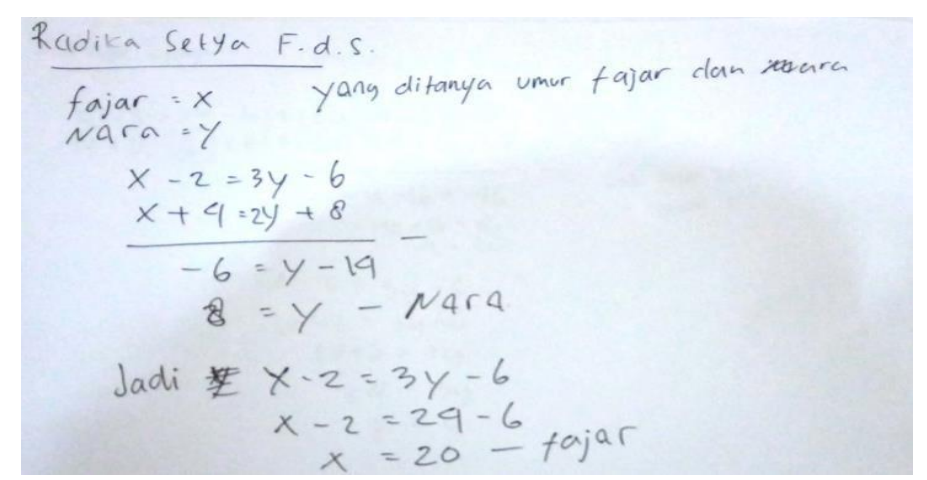

Gambar 5. Hasil Pekerjaan Siswa ke 4

Dapat dilihat dari jawaban siswa ke 4. Sesuai dengan indikator komunikasi matematis siswa ke 4 menuliskan informasi ditanya saja dalam permasalahan dengan benar. Siswa ke 4 menuliskan kalimat matematika dalam permasalahan yang diberikan dengan benar tetapi tidak lengkap. Siswa ke 4 menuliskan langkah-langkah dalam menyelesaikan permasalahan tidak lengkap tetapi benar. Siswa ke 4 tidak memberikan kesimpulan diakhir penyelesaian. Siswa ke 4 menuliskan simbol matematika dengan lengkap dan benar.

Pada tes kemampuan komunikasi matematis lisan siswa ke 4 mengucapkan informasi yang terdapat dalam permasalahan tidak lengkap dan tidak lancar tetapi benar. Siswa ke 4 tidak dapat mengucapkan permisalan masalah kedalam model matematika. Siswa ke 4 tidak dapat menjelaskan langkah-langkah penyelesaian masalah. Siswa ke 4 tidak memberikan kesimpulan diakhir penyelesaian. Siswa ke 4 mengucapkan simbol matematika dengan tidak lengkap dan tidak lancar tetapi benar.

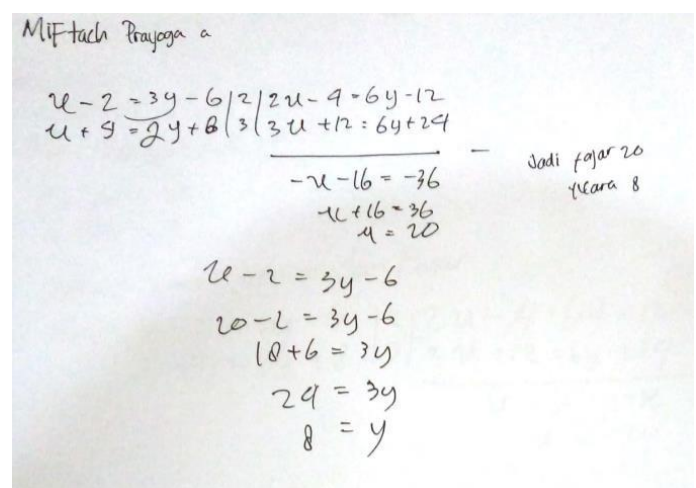

Gambar 6. Hasil Pekerjaan Siswa ke 5

Dapat dilihat dari jawaban siswa ke 5. Sesuai dengan indikator komunikasi matematis siswa ke 5 tidak menuliskan informasi dalam permasalahan. Siswa ke 5 tidak menuliskan kalimat matematika dari permasalahan yang diberikan. Siswa ke 5 menuliskan langkah-langkah dalam menyelesaikan permasalahan dengan lengkap dan benar. Siswa ke 5 memberikan kesimpulan diakhir penyelesaian dengan lengkap dan benar. Siswa ke 5 menuliskan simbol matematika tidak lengkap tetapi benar. 
Pada tes kemampuan komunikasi matematis lisan siswa ke 5 mengucapkan informasi yang terdapat dalam permasalahan tidak lengkap dan tidak lancar tetapi benar. Siswa ke 5 tidak dapat mengucapkan permisalan masalah kedalam model matematika. Siswa ke 5 menjelaskan langkahlangkah penyelesaian masalah dengan benar, runtut tetapi tidak lancar. Siswa ke 5 tidak memberikan kesimpulan diakhir penyelesaian. Siswa ke 5 tidak dapat mengucapkan simbol matematika.

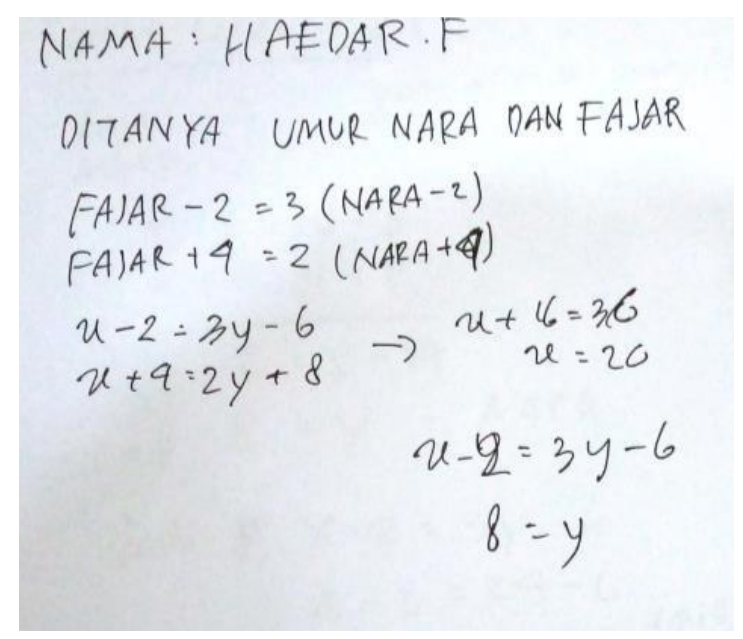

Gambar 7. Hasil Pekerjaan Siswa ke 6

Dapat dilihat dari jawaban siswa ke 6. Sesuai dengan indikator komunikasi matematis siswa ke 6 menuliskan informasi ditanya saja dalam permasalahan dengan benar Siswa ke 6 menuliskan kalimat matematika dalam permasalahan yang diberikan dengan benar tetapi tidak lengkap. Siswa ke 6 menuliskan langkah-langkah dalam menyelesaikan permasalahan tidak lengkap tetapi benar. Siswa ke 6 tidak memberikan kesimpulan diakhir penyelesaian. Siswa ke 6 menuliskan simbol matematika tidak lengkap tetapi benar.

Pada tes kemampuan komunikasi matematis lisan siswa ke 6 mengucapkan informasi yang terdapat dalam permasalahan lengkap, benar, tetapi tidak lancar. Siswa ke 6 tidak dapat mengucapkan permisalan masalah kedalam model matematika. Siswa ke 6 tidak dapat menjelaskan langkah-langkah penyelesaian masalah. Siswa ke 6 tidak memberikan kesimpulan diakhir penyelesaian. Siswa ke 6 tidak mampu mengucapkan simbol matematika.

Kemampuan komunikasi matematis siswa sebelum dan sesudah menggunakan media pembelajaran Geogebra dapat dilihat pada Tabel 3.

Tabel 3. Daftar Nilai Ulangan Harian dan Tes Siswa

\begin{tabular}{|c|c|c|c|c|c|}
\hline No. & Subjek & $\begin{array}{c}\text { Nilai } \\
\text { UH }\end{array}$ & $\begin{array}{c}\text { Kelompok } \\
\text { Siswa }\end{array}$ & $\begin{array}{c}\text { Nilai } \\
\text { Tes }\end{array}$ & $\begin{array}{c}\text { Kelompok } \\
\text { Siswa }\end{array}$ \\
\hline 1 & Siswa ke 1 & 65 & Tinggi & 73 & Tinggi \\
\hline 2 & Siswa ke 2 & 70 & Tinggi & 68 & Tinggi \\
\hline 3 & Siswa ke 3 & 36 & Rendah & 50 & Sedang \\
\hline 4 & Siswa ke 4 & 45 & Sedang & 49 & Sedang \\
\hline 5 & Siswa ke 5 & 45 & Sedang & 44 & Rendah \\
\hline 6 & Siswa ke 6 & 30 & Rendah & 38 & Rendah \\
\hline
\end{tabular}


Berdasarkan Tabel siswa ke 1 dengan nilai 65 berada pada kelompok komunikasi matematis tinggi pada nilai UH, mengalami peningkatan nilai pada hasil tes. Sesuai dengan kemampuan komunikasi matematis siswa, hasil tes siswa ke 1 berada pada kelompok komunikasi matematis tinggi. Sehingga siswa ke 1 tetap berada pada kelompok komunikasi matematis tinggi.

Siswa ke 2 dengan nilai 70 berada pada kelompok komunikasi matematis tinggi pada nilai $\mathrm{UH}$, mengalami penurunan nilai pada hasil tes. Sesuai dengan kemampuan komunikasi matematis siswa, hasil tes siswa ke 2 berada pada kelompok komunikasi matematis tinggi. Sehingga siswa ke 2 tetap berada pada kelompok komunikasi matematis tinggi.

Siswa ke 3 dengan nilai 36 berada pada kelompok komunikasi matematis rendah pada nilai $\mathrm{UH}$, mengalami peningkatan nilai pada hasil tes. Sesuai dengan kemampuan komunikasi matematis siswa, hasil tes siswa ke 3 berada pada kelompok komunikasi matematis sedang. Sehingga siswa ke 3 mengalami peningkatan dari kelompok komunikasi matematis rendah menjadi kelompok komunikasi matematis sedang.

Siswa ke 4 dengan nilai 45 berada pada kelompok komunikasi matematis sedang pada nilai $\mathrm{UH}$, mengalami peningkatan nilai pada hasil tes. Sesuai dengan kemampuan komunikasi matematis siswa, hasil tes siswa ke 4 berada pada kelompok komunikasi matematis sedang. Sehingga siswa ke 4 tetap berada pada kelompok komunikasi matematis sedang.

Siswa ke 5 dengan nilai 45 berada pada kelompok komunikasi matematis sedang pada nilai UH, mengalami penurunan nilai pada hasil tes. Sesuai dengan kemampuan komunikasi matematis siswa, hasil tes ke 5 berada pada kelompok komunikasi matematis rendah. Sehingga siswa ke 5 mengalami penurunan dari kelompok komunikasi matematis sedang menjadi kelompok komunikasi matematis rendah.

Siswa ke 6 dengan nilai 30 berada pada kelompok komunikasi matematis rendah pada nilai UH, mengalami peningkatan nilai pada hasil tes. Sesuai dengan kemampuan komunikasi matematis siswa, hasil tes siswa ke 6 berada pada kelompok komunikasi matematis rendah. Sehingga siswa ke 6 tetap berada pada kelompok komunikasi matematis rendah.

Berdasarkan penelitian yang telah dilaksanakan, Geogebra dapat meningkatkan komunikasi matematis siswa. Akan tetapi hal ini tidak berlaku untuk semua keadaan, hanya dalam keadaan tertentu seperti; menjelaskan dan menuliskan apa yang diketahui dan ditanya, mengubah masalahkedalam bentuk matematika, menjelaskan dan menuliskan langkah-langkah dalam menyelesaikan permasalahan, memberikan kesimpulan diakhir penyelesaian, mengucapkan dan menuliskan simbol matematika. Ada beberapa faktor yang dapat menyebabkan meningkatnya komunikasi matematis siswa. Kemampuan komunikasi matematis siswa dideskripsikan berdasarkan faktor - faktor yang meliputi proses pembelajaran, sikap dan pemahaman siswa, serta pembiasaan atau pemberian soal-soal yang dapat mengukur kemampuan komunikasi matematis secara rutin (Hikmawati, Nurcahyo, \& Balkist, 2019). Jadi adanya Geogebra tidak bisa memberi nilai mutlak bahwa komunikasi matematis siswa akan meningkat. Hasil penelitian yang telah dilakukan sesuai dengan penelitian yang pernah dilakukan oleh Nopiyani dengan judul "penerapan Pembelajaran Matematika Realistik berbantuan Geogebra untuk Meningkatkan Kemampuan Komunikask Matematis Siswa SMP" dan penelitian yang dilakukan oleh Fahmi yang berjudul "Peningkatan Kemampuan Penalaran dan Komunikasi Matematik Siswa Melalui Model Pembelajaran Berbasis Masalah Berbantuan Geogebra di Kelas VIII SMP N 1 Samudera", yakni Geogebra membantu siswa dalam meningkatkan komunikasi matematis (Nopiyani, Turmudi, \& Prabawanto, 2019; Fahmi, Syahputra, \& Rajagukguk, 2017). 


\section{Kesimpulan}

Sesuai dengan latar belakang yang telah disampaikan. Terkait pengembangan komunikasi matematis siswa pada pokok bahasan Sistem Persamaan Linier Dua Variabel menggunakan Geogebra. Maka dilakukan analisis aktivitas siswa ketika berlangsungnya pembelajaran menggunakan Geogebra. Hal ini sesuai dengan tujuan penelitian yaitu, mengetahui aktivitas belajar siswa pada pokok bahasan Sistem Persamaan Linier Dua Variabel menggunakan Geogebra. Berdasarkan analisis data hasil penelitian dan pembahasan mengenai analisis penerapan media pembelajaran Geogebra dalam meningkatkan kemampuan komunikasi matematis siswa pokok bahasan Sistem Persamaan Linier Dua Variabel dapat disimpulkan bahwa.

Aktivitas belajar siswa pada pokok bahasan Sistem Persamaan Linier Dua Variabel menggunakan Geogebra dapat diketahui melalui hasil observasi. Berdasarkan hasil observasi siswa antusias dalam mengikuti pembelajaran Sistem Persamaan Linier Dua Variabel menggunakan Geogebra. Mereka mengikuti proses pembelajaran sesuai dengan apa yang direncanakan, dan sesuai dengan indikator komunikasi matematis siswa yang terdapat pada lembar observasi.

Penerapan media pembelajaran Geogebra dapat meningkatan kemampuan komunikasi matematis siswa pada pokok bahasan Sistem Persamaan Linier Dua Variabel. Siswa menjadi lebih paham dan mampu menyampaikan pemahamannya terkait permasalahan dan proses penyelesaiannya. Hal ini dapat dilihat dari proses pengerjaan siswa yang sesuai dengan indikator komunikasi matematis siswa.

Kemampuan komunikasi matematis siswa yang merujuk pada indikator komunikasi matematis dideskripsikan berdasarkan faktor- faktor yang meliputi proses pembelajaran, sikap dan pemahaman siswa, serta pembiasaan atau pemberian soal-soal yang dapat mengukur kemampuan komunikasi matematis secara rutin.

Berdasarkan hasil penelitian yang didapat, ada beberapa saran yang diberikan yaitu, (1) Bagi siswa, disarankan untuk lebih sering berlatih dan mempresentasikan pemahaman yang dimiliki pada suatu permasalahan; (2) Bagi guru, diharapkan lebih banyak memberikan latihan soal yang menggali kemampuan komunikasi matematis, serta lebih mengenalkan penggunaan media pembelajaran seperti Geogebra agar lebih meningkatkan pemahaman siswa; (3) Bagi peneliti lain, sebaiknya media pembelajaran yang digunakan untuk penelitian merupakan media pembelajaran yang lebih inovatif dan variatif, serta lebih mampu meningkatkan kemampuan komunikasi matematis siswa.

\section{Daftar Pustaka}

Monalisa, L. A. dan D. Trapsilasiwi. (2015). Penerapan Pembelajaran Kooperatif Tipe Jigsaw Pada Pokok Bahasan Keterbagian Bilangan Bulat Untuk Meningkatkan Aktivitas Mahasiswa Semester VI Tahun Ajaran 2014-2015 Program Studi Pendidikan Matematika Fakultas Keguruan Dan Ilmu Pendidikan Universitas Jember. Pancaran Pendidikan. 4(2):173-180. https://jurnal.unej.ac.id/index.php/pancaran/article/view/1561/1277

Faradina, A. T. E., Sunardi, \& Trapsilasiwi, D. (2016). Analisis Kemampuan Komunikasi Matematis Siswa Dalam Memahami Masalah Segiempat. Kadikma, 7(1), 46-56. https://jurnal.unej.ac.id/index.php/kadikma/article/view/5467/4101

Suherman, E. (2013). Strategi Pengajaran Matematika Kontemporer. Bandung: JICA.

Sholikhah, M, Trapsilasiwi, D., \& Suharto. (2018). Kemampuan Komunikasi Matematis Siswa 
Tunagrahita Ringan Smalb-C Negeri Jember Dalam Menyelesaikan SoalPenjumlahan Dan Pengurangan Aljabar Menggunakan Alat Peraga Kertas Aljabar. Kadikma, 9(2), 98107.https://jurnal.unej.ac.id/index.php/kadikma/article/view/9781/6414

Siregar, N. R. (2017). Persepsi Siswa Pada Pelajaran Matematika: Studi Pendahuluan PadaSiswa yang Menyenangi Game. Prosiding Temu Ilmiah X Ikatan Psikologi PerkembanganIndonesia, 224-232.http://jurnal.unissula.ac.id/index.php/ippi/article/view/2193/1655

Oktavianingtyas, E., F. S. Salama, A. Fatahillah, L. A. Monalisa, and T. B. Setiawan. (2018). "Development 3D Animated Story as Interactive Learning Media with Lectora Inspire and Plotagon on Direct and Inverse Proportion Subject," J. Phys. Conf. Ser., vol. 1108, no. 1, https://iopscience.iop.org/article/10.1088/1742-6596/1108/1/012111/pdf

Agung, I. \& Masduki, (2013). Peningkatan Kemampuan Pemecahan Masalah danKomunikasi Matematis SMA dengan Pemanfaatan Software Core Math Tools, HasilPenelitian (Seminal Nasional Pendidikan Matematika, Surakarta 5 Mei 2013) Pendidikan Matematika, FKIP, Universitas Muhammadiyah Surakarta. https://publikasiilmiah.ums.ac.id/bitstream/handle/ 11617/3248/7_Peningkatan\%20Kemampuan\%20Pemecahan\%20Masalah\%20Dan\%20

Komunikasi\%20Matematis\%20Sma\%20Dengan\%20Pemanfaatan\%20Software\%20

Core\%20Math\%20Tools.pdf?sequence $=1 \&$ is Allowed=y

NCTM. (2000). Principles and Standards for School Mathematics. Retrieved fromwww.nctm.org

Kurnia, R.N., Setiawani, S., dan Kristiana, A.I. 2015. Analisis Kemampuan Komunikasi Matematis Siswa Kelas VIIC SMP Negeri 1 Rogojampi Tahun Pelajaran 2014/2015. Jember: Universitas Jember.

Laksananti, P. M., Setiawan, T. B., \& Setiawani, S. (2017). Analisis KemampuanKomunikasi Maematis dalam Menyelesaikan Masalah Pokok Bahasan Bangun Datar SegiEmpat Ditinjau dari Kecerdasan Emosional Siswa Kelas VIII-D SMP Negeri 1Sumbermalang. Kadikma, 8(1), 88-96. https://jurnal.unej.ac.id/index.php/kadikma/article/view/5268/3987

Nurlaila, S., Sariningsih, R., \& Maya, R. (2018). Analisis Kemampuan KomunikasiMatematis Siswa Smp Terhadap Soal-Soal Bangun Ruang Sisi Datar. Jurnal PembelajaranMatematika Inovatif, 1(6), 1113- 1120. https://journal.ikipsiliwangi.ac.id/index.php/jpmi/article /download/2025/331

Putri, E. (2018). Perbedaan Hasil Belajar Ekonomi Menggunakan Metode Problem Solving (Pemecahan Masalah) dengan Metode Ceramah pada Siswa Kelas X Ips SMAN 3 Teladan Bukittinggi. Jurnal Pendidikan Ekonomi, 11(2), 99-106. http://journal2.um.ac.id/index.php /jpe/article/view/5174/2915

Fatoni, M. faizal, Dafik, \& Fatahillah, A. (2017). Pengembangan Media Pembelajaran Interaktif Online Menggunakan KelasKita Berbantuan Software Geogebra pada Materi Persamaan Kuadrat. Kadikma : Jurnal Matematika Dan Pendidikan Matematika, 8(2), 24-

33. Retrieved from https://jurnal.unej.ac.id/index.php/kadikma/article/view/6070/4489

Minarti. (2013). Analisis Tingkat Kemampuan Siswa dalam Memecahkan Masalah BentukSoal Cerita pada Materi Sistem Persamaan Linier Dua Variabel. Jurnal Online UniversitasNegeri Surabaya [Online]. Vol 2 No 1. Tersedia: http://ejournal.unesa.ac.id/article/6264/30/ article.pdf

Hikmawati, N. N., Nurcahyono, N. A., \& Balkist, P. S. (2019). Kemampuan Komunikasi Matematis Siswa Dalam Menyelesaikan Soal Geometri Kubus Dan Balok. Prisma, 8(1), 68. https://doi.org/10.35194/jp.v8i1.648

Nopiyani, D., Turmudi, \& Prabawanto, S. (2016). Penerapan Pembelajaran Matematika Realistik 
Berbantuan Geogebra untuk Meningkatkan Kemampuan Komunikasi MatematisSiswa SMP. Mosharafa: Jurnal Pendidikan Matematika, 5(2), 45-52. https://doi.org/10.31980/ mosharafa.v7i3.133

Fahmi, A., Syahputra, E., \& Rajagukguk, W. R. (2017). Peningkatan Kemampuan Penalaran dan Komunikasi Matematik Siswa Melalui Model Pembelajaran Berbasis Masalah Berbantuan Geogebra di Kelas VIII SMP N 1 Samudera Akmal. 10(3), 27-39. 